\title{
SZERB László
}

\section{A MAGYAR MIKRO-, KIS- ÉS KÖZÉP. VÁLLALATOK VERSENYKÉPESSÉGÉNEK MÉRÉSE ÉS VIZSGÁLATA}

A cikk célja magyar mikro-, kis- és közepes méretú cégek versenyképességének vizsgálata. Mivel az eddigi versenyképességi mutatók nagyvállalatokra készültek, egy új koncepcionális modellt kellett alkotni. A rétegzetten reprezentatív felmérés során kapott 695-ös erôsségú mintából álló hazai kkv-szektor elemezését az új modell 21 változója és 7 pillérje mentén végzi el a szerzớ. A szúk keresztmetszetekért történố büntetés (PFB) egyedi módszerének segítségével lehetséges a vállalatok versenyképességének gyenge pontjait feltárni. A versenyképesség hét pillérje, a Kereslet, a Kínálat, a Fizikai erőforrások, a Humán eróforrások, az Innováció, a Networking és az adminisztratív Rutinok, továbbá a versenyképességi teljesítmények tényezói mentén képzett 8 klaszter egyrészt a hazai kkv-szektor csoportjai közötti jelentôss különbségeket, másrészt a klasztereken belül a hasonlóságokat szemlélteti. Az átlagos versenyképesség a pontok alapján igen alacsony (1,96/7), különösen problematikus a kínálati, az innovációs és az együttmúködést mutató networking pillérek mentén. A gyengébb versenyképességú csoportok számosabbak és homogénebbek a magasabb verpillérek mentén. Agy senyképességúeknel. A PFB--ódszer alkán is, ezt négy cég példáján szemlélteti a cikk. Bár a módszer hasznosnak bizonyult, több területen szükséges továbbfejleszteni, hogy ténylegesen alkalmazható legyen gazdaságpolitikai javaslatok megfogalmazására és cégszintú stratégiai javaslatok adására.'

Kulcsszavak: versenyképesség, versenyképességi mutatók, kkv-szektor

A versennyel kapcsolatos felfogást hosszú ideig a Ricardóig visszavezethetó költségközpontú komparatív elő́nyökön nyugvó megközelítés határozta meg. Elsősorban Michael Porter munkássága nyomán indult e és erősödött fel az az irányzat, amely az innováción és a megújuláson alapuló kompetitív előnyökre helyezte a megújuláson alapuló kompetituv elônyökre helyez a hangsúlyt (Porter, 1990). Számos, többek között europai unióbeli ország és Magyarország is gazdaságpolitikájának egyik
növelését tartja.

Az elmúlt két évtizedben a versenyképességi kutatások megsokszorozódtak. Az országvizsgálatok melle különösen a regionális elemzések népszerúsége növekedett. Széles körben ismertté vált az országok versenyképességét mérố két komplex index, a Világgazdaság Fórum Világ Versenyképességi Indexe (Schwab, 2009) és az IMD versenyképességi indexe is (IMD yearbook 2010).

A hazai versenyképességi vizsgálatok meglehetôsen gyorsan követtek a kulfoldi valtozásokat. Ebben úttörő szerepet játszott Török Ádám, aki elsősorban a versenyképesség elméleti kérdéseivel, koncepcionális változásaival foglalkozott (Török, 1989; 1999; 2007) A vállalati versenyképesség szisztematikus mérését a Budapesti Corvinus Egyetem (illetve elódje, a BKE) Vúllusti Corvinus Egyetem (illeve elode, a BKE) Célo

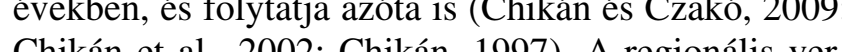
Chikán et al., 2002; Chikán, 1997). A regionalis versenyképességi kutatások pedig elsősorban a Szeged Tudomanyegyetemen, Lengyel Imre vezetésével folynak (Lengyel, 2000; 2003; 2006), a Gazdaságkutató Intézet pedig rendszeresen végzi a versenyképesség komplex vizsgálatát az IMD nemzetközi felmérés módszertanának megfelelóen (Viszt, 2006; 2009)

A vállalati versenyképességi vizsgálatok döntố mértékben a nemzeti és a helyi környezet függvényé- ben modellezik a vállalatok versennyel kapcsolatos magatartását és stratégiáját (Nelson, 1992). Ez a fajta megközelítés azt feltételezi, hogy az adott térségben makrogazdasági vagy az iparági sajátosságok és intézmények határozzák meg döntô mértékben a régióban vagy klaszterben tevékenykedó cégek teljesítményét. $\mathrm{Az}$ ilyen jellegú empirikus tanulmányok jellemzóe aggregált adatokat alkalmaznak (top-down megközelítés). Mindamellett, hogy az intézményi fejlődés vizsgálatára ez a megközelítés alkalmas, nem segít bennünket abban, hogy megértsük a vállalatok magatartáś́t, vagy magyázatot taĺljunk az egy ipaga-

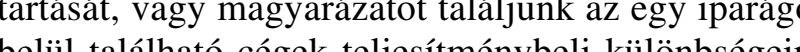

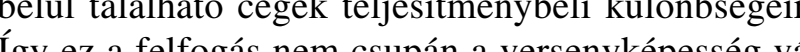
lgy ez a felfogás nem csupán a versenyképesség válalati szintu belsó tényezôt hagyja figyelmen kivin, de az adatok aggregálassa révén esetleg téves követ keztetéseket vonunk le. A javasolt gazdaságpolitik intézkedések pedig jobb esetben hatékonytalanok rosszabb esetben kifejezetten károsak is lehetnek Krugman, 1994 kritikáját). Ennek tükrében úgy vélem, hogy a vállalati versenyképesség vizsgálatához a vállalati szintú elemzés megfelelôbb eszköz leh (bottom-up felfogás)

A hazai vállalati versenyképesség-kutatásoknak is jellemzője, hogy döntô mértékben a versenyképességet befolyásoló intézményi tényezók elemzésére fók Jellemzo, hogy az intézményi feltételek vállalati kö ségtényezókre gyakorolt hatása szerepel a középpon ban (l. pl. Borsi - Papanek - Tompa, 2007; Hoványi, 1999; Torok, 2007). A versenyképessêg intézményi tényezơrớl - fôleg az adózás, a vállalkozásindítás és az innováció eseteiben - nyújt áttekintést a Versenyképe ségi Kerekasztal nemrégiben kiadott tanulmánykötete is (Veress, 2009). A BCE-kutatásokat kivéve viszont elvétve találni olyan vállalati versenyképességi vizsgálatot, amely a vállalati belsố tényezők, eróforrások elemzésén alapulna.

A versenyképesség vizsgálatának egy további fontos szempontja a cég mérete. A legtöbb elemzés elsősorban a nagy, gyakran multinacionális cégekre vấgy klaszterekre koncentrál (Chikán, 2006; Leégek 2001; Pore, 1990; 1998; Rugmín, 206; Lengyel, Usy, Poter, 1990; 1998; Rugm es- Verbeke, 2001). Ugyanakkor a kisvallalati versenyképességról relatíve kevés tanulmány lelhetó fel. Ebben biztosan szerepet játszik Porter is, aki azt állítja, hogy a versenyképe séget olyan szektorokban érdemes vizsgálni, ahol az adott országnak komparatív előnye van (Porter, 1990). Ugyanakkor Magyarországon a kis- és középvállala szektorban található a cégek 99,9\%-a, a versenyszfér foglalkoztatottjainak nagyjából 70\%-a, és a kicsik termelik a GDP mintegy 55\%-át (Kkv-k helyzete, 2008). Más országok esetében is döntố mértékben hasonlo arányokat kapunk. Így, Porterrel ellentétben én úgy vélem, hogy egy ország versenyképességének vizsgálatakor nem tekinthetünk el a kisebb méretú cégek elemzésétól sem.

A hazai kisvállalatok versenyképességével kevés tanulmány foglalkozik. Az IMD legutóbbi versenyképességi felmérese szerint a magyar kkv-k versenyképessége a vizsgált országok között a legalacsonyabb volt, még az újonnan csatlakozott EU-országokhoz képest is. Ugyanakkor a nagyvállalatok múködési hatékonySága a nemzetközi átlagot meghaladta (Viszt, 2009). A gyene versenyképeść ok A gy a ver A gye versenyképesség okain, valla tényezoand ari hogy a hazai knv-szektor intézmenyi, szabályozási feltételeit vizsgálhassuk (Kkv-k helyzete, 2008). Elméletileg is igényes, aggregált adatokon nyugvó kkv-szektor-elemzést prezentál Némethné (2009). Válalati szintú adatokon és belsố tényezókön alapulnak Kadocsa (2006) és Márkus et al. (2008) kisebb mintás vizsgálatai. A hiányokat pótlandó, a hazai kis- és középvállalatokra fókuszáló átfogó, elméleti alapokon nyugvó empirikus elemzés értékes hozzájárulást jelenthet a magyar kkv-szektor versenyképességi szintjének es problémáinak a megoldásához is.

Ezen tanulmány alapvetô célja, hogy egy olyan, elméleti alapokon álló versenyképességi indexet mutasson be, amely alkalmas arra, hogy a kisebb méretú vállalatok versenyképességét mérje. A vállalati szintú versenyképesség esetében, tudomásom szerint Chikán (2006) publikálta az első versenyképességi indexet, mely azonban elsősorban a nagyvállalati versenyképesség mérésére alkalmas. Hasonlóan Chikán Attila megközelítéséhez, az itt ismertetésre kerülố kis- és középvállalati versenyképességi index is a vállalati belsố tényezôkre helyezi a hangsúlyt, és döntố mértékben eltekint az intézményi, környezeti feltételek elemzésétől. Újdonságot elsősorban nem is az index, hanem az indexet alkotó belső tényezók, pillérek egyedi kombinálása jelenti, amely optimálisnak a versenyképesś́g hét pillérjének kiegyensúlyoznak kiegyensúlyozott

A következókben először egy rövid elméleti áttekintést teszek. Majd a vizsgálat alapjául szolgáló koncepcionális modellt mutatom be, amely alkalmas a kisebb méretú cégek versenyképességének vizsgálatára. Ezután mutatom be az adatbázist és a feldolgozás módszertanát. Az újonnan alkotott, a szúk keresztmetszetekért történó büntetés (PFB) analitikai módszertana lehetôvé teszi, hogy kiszámíthassuk a versenyképességi pontokat, elemezzük a versenyképességi tényezóket és a konfigurációkat. A kutatási eredményeket a számított 
versenyképességi értékek és a versenyképesség más mérőszámai közötti kapcsolatot a korrelációs koefficiensek segítségével vizsgálom. A klaszterelemzési technika a domináns versenystratégiák, a versenyképessé tényezőinek és a vállalatok teljesítményének azonos tását teszi lehetővé. Ugyanakkor a PFB-módszer alkalmas arra is, hogy vállalati szintú javaslatokat tegyek láncszem javítása révén. Végezetül a tanulmány legfontosabb megállapításait foglalom össze.

\section{A vállalati versenyképesség vizsgálatának elméleti alapjai}

A lassan könyvtárnyivá duzzadó versenyképesség irodalomban és a különböző irányzatok között má ma is meglehetósen nehéz eligazodni. E tanulmány keretén belül nem tartom feladatomnak, hogy részletes irodalomfeldolgozást végezzek, a témában mấ Magyarországon is több színvonalas elemzés, köny és Ph.D. disszertáció áll rendelkezésre (Borsi, 2005; Czakó, 2000; Chikán - Czakó, 2009; Némethné, 2009 Lengyel, 2003; Török, 1999). Fontosnak tartom viszont, hogy igazodási pontként el lehessen helyezni az általam kutatott témát, a kisvállalati versenyképessé elemzését.

A versenyképességet vizsgálhatjuk makro-, mezoés mikroszinten egyaránt (Lengyel, 2000). A makroszintú elemzés alapegysége általában az ország vagy országcsoport (pl. Európai Unió) és a verseny színtere a világgazdaság vagy annak nagy egységei, földré szei. A regionális és az iparági megközelítés alkotja mezoszintú elemzés szintjét. Az utóbbi idôben egyre többen vizsgálják a kisebb regionális egységek, városok, kisrégiók versenyképességét is (Acs, 2006; Ward és - Jonas, 2004). Végül, de a jelen elemzésünk szempontjából legfontosabb szintként, a vállalatok képezik a versenyképesség mikroszintjét.

A különböző szinteknek megfelelő́n az egyes szerzớk más-más tényezóknek tulajdonítanak kiemelkedố jelentőséget. A Török-féle (1999) tipologiźlás költjelentôséget. Á Tó ségalapú kínalatiés piaci teljesítményen alapuló keresleti megközelítéseket tárgyal. Az országok közötti öszszés kínálatiti tényezóket is kombináló gyémánt modellt és kínálatí tényezôket is kombináló gyémánt model használják, amely a versenyképesség négy kulcsfontosságú elemét - a tényezőellátottságot, a keresleti viszonyokat, a kapcsolódó és beszállító iparágakat, valamint a vállalati struktúrát és versenyt - azonosítja. Ezen felfogás mentén készül az egyes országok versenyképességét mérố két nagy index, a Világgazdasági Fórum Globális Versenyképességi Index (Schwab,
2009) és az IMD versenyképességi indexe is (IMD Yearbook, 2009). A versenyképességet regionális szinten elemzók figyelmüket elsôsorban az agglomerációs hatásokra és az intézményi tényezókre fordítják (Fujita et al., 1999; Scott - Storper, 2003). Agglomerációs effektusok, egymással versenyző, de ugyanakkor kulcsterületeken együttmúködố vállalati kapcsolatok és tudás, továbbá ezt támogató helyi intézményi viszonyok határozzák meg a klaszterek versenyképességét (Lengyel, 2001; Porter, 1998). Az iparági versenyképesség dinamikáját elemzók elsôsorban a hosszú távû́ pesség dinamikaját elemzók elsôsorban a hosszú távú technológiai fejlódéssel és innovációval osszhangban folytatnak kutatást (Jovanovich - McDonald, 1984,; Abban még a versenyképesség-felfogás két nagy, sokszor egymással vitatkozó képviselóje, Porter (1998) és Krugman (1994) között is egyetértés van, hogy a versenyképesség alapját a vállalati szint jelenti. (Krugman szerint egyedül itt van értelme versenyképességrốl beszélni.) Ezt a vállalati szintú versenyképességet ugyanakkor két különböző felfogás mentén vizsgálták. Az elsố a Porter- féle öt eró modell, amely az iparági verseny jellemzőire fókuszál. A vállalatok vezetôi a külsố tényezóknek, az iparági trendeket leíró öt erónek megfelelően alakíthatják ki azt a stratégiát, amely versenyelő́nyt biztosíthat a többi céggel szemben.

A Porter-féle megközelítés gyenge pontja, hogy kihagyja az elemzésból a vállalatok rendelkezésére alló erôforrásokat, a belsố tényezôket (Grant, 1991). A versenyképesség másik felfogása éppen ezekből a cegspecifikus jellemzókbő́l indul ki. A számos elmélet (Ambastha - Momaya, 2004) közül talán a legismertebb az erőforrás-alapú elméletek csoportja (RBV) (Barney, 1991; Wernerfelt, 1984), amelyek közös jellemzôje, hogy a vállalati belsô jellemzóket tartja a versenypozíciót meghatározó elsődleges tényezónek a külső intézményi tényezókkel, vagy éppen az iparági jellemzókkel szemben (Foss - Knudsen, 1996)

Barney (1991) az egyedi erőforrások négy fontos tulajdonságát írja le. Ezek (1) az értékesség, ami az erớforrás hatékonyságát és eredményességét jelenti, (2) a ritkaság az erőforrás sajátosságára, egyediségére utal, (3) a tökéletlen reprodukálhatóság az adott erôforrás más által történó lemásolásának a nehézségeire utal, és (4) a helyettesíthetốség, amely magába foglalja az alternatív eröforrások potenciális rendelkezésre állását. Az erốforrás, ami lehet eszköz, kompetencia, szervezeti folyamat, információ, tudás vagy kapacitás, egyedinek minősül, ha értékes, ritka, nehéz lemásolni és nincsen közeli helyettesítési lehetôsége. Az egyedi jellegzetességú eróforrások lehetővé teszik az átlag feletti jövedelmezőség és a tartós versenyelóny elérését
(Rugman - Verbeke, 2002). Az erôforrás-alapú stratégia lényege, hogy a belsố erő́forrásokat harmonizálni kell a külsố környezeti tényező́kkel (Grant, 1996). Bá a kétfajta megközelítés első ránézésre meglehetôse markánsan különbözik, nem lehetetlen az összeegyeztetés: a belsố erőforrásokat összhangba lehet hozni az iparági környezeti tényezókkel. A következókben ezt szintetizált felfogást igyekszem követni a vállalati versenyképességi index kialakításánál.

Mint azt az előzókben már említettem, az eddigi hazai versenyképességi vizsgálatok döntô mértékben a Porter-féle megközelítésre és a versenyképességet bePortýs folyásoló intéznényi viszonyok elemzésére, valamint regionalis versenyképességre fókuszáltak. Ezzel szemben a Chikán-fele vallala versenyképesség-vizsgál az erơforras-elméletbôl indul ki (Chikán, 2006). Ez a felfogast követem én is. Ennek megfelelóen a versenyképesség alapvetôen a vállalati belsố erőforráso rendelkezésre állásán és szintjén, a kompetenciáko alapul. Ugyanakkor a kompetenciákat a stratégia keretén belül az iparági kínálati és keresleti viszonyokkal, tágabban értelmezve pedig a porter-i öt eróvel kell összhangba hozni. Figyelembe kell venni azt is, hogy az erőforrások rendelkezésre állása jelentősen befolya solja, módosíthatja a vállalat stratégiai lehetóségeit. A kisebb méretú cégek eróforrásai külö lëonetóségeit. zottak, így a legtöbb ilyen vállalat egy szúkre szabot zottak, így a legtöbb ilyen

A hazai kisvállalatok versenyképességére vonatkozó információk, a környezeti, szabályozási tényezók és a kkv-szektor összehasonlító alapadatai a kkv-k helyzetéról szóló éves jelentésekben találhatóak (Kkvhelyzete, 2009). Vállalati szintú kisvállalati versenyképesség-vizsgálatokkal viszont alig lehet találkozn Kadocsa (2006) a hazai kkv-k azon menedzsment és szervezeti módszereit elemezte, amelyek pozitíva hatottak a versenyképességre. Márkus et al. (2008) versenyképességre ható tényezốk egy részét, a kutatásfejlesztést, a célpiacok alakulását, a változásokhoz fưző́dô viszonyt, a marketing költségvetését, a stratégin szövetségben való részvételt és a munkeró fluktuáci-

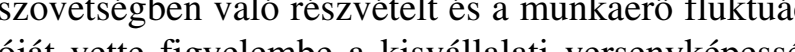
oját vette foyelon index kiala féle belsố tényezók Aonbináására alkalmas modellt mutat be Nemethné, aki azonban ezt az elemzési eszközt a kkv-k csoportjára és nem egyedi elemzésre kalmazta (Némethné, 2009): a kkv-k versenyképessegét befolyásoló tényezók elemzése a tényező́k szerint egyenként, a kkv-szektorra vonatkozó aggregált adatokon, és nem az indexképzés logikájának megfelelóen, a tényezók szerinti komplex módon és egyedi vállalati szinten történt.

\section{VEZETÉSTUDOMÁNY}

\section{koncepcionális model}

A kialakítandó koncepcionális modell és annak gyakorlati használhatósága kapcsán három, egymássa összefüggésben álló problémát kell megoldani. Ezek a (1) a modellt alkotó tényezók definiálása, (2) a modellt alkotó elemek kombinálása, és végül (3) a kisvállalati specialitások azonosítása.

1) A koncepcionális modellt alkotó tényezók meghatározásához elôször definiálnunk kell a versenyképességet, mégpedig ezen belül is a vizsgálatunk tárgyául szolgáló vállalati versenyképességet. Alapvetően tudom fogadni azt a Chikán - Czakó-féle (2006) meghatározást, amely a vállalati versenyképességet a vállalat azon képességével azonosítja, ahogyan az verenytársakhoz viszonyítva inkább képes megfelelni a ogyasztói igények kielégítésének, olyan módon, hogy Z nem sérti a társadalmi normákat és nyereséget biztosít a cégnek is. Ehhez hozzátartozik a környezeti és a vállalaton belüli változások érzékelésének és az erre történő reagálásnak a képessége.

A fenti definíciót azonban adaptálnunk kell egy kalmazásra is képes. Ez azt jelenti, hogy sokkal konkrétabban kell megfogalmazni a versenyképességeket alkotó tényezóket. Az adaptációt leginkább korlátozó faktor a változók és az adatok rendelkezésre állása. A praktikus megfontolásokat, valamint a stratégiai menedzsment, a kisvállalati és az erôforrás-elmélet irodalmát figyelembe véve (Grant, 1991; Lengnick, 1992; Man et al., 2002; McGahan, 1999; Peteraf, 1993; Ray et al., 2004) a vállalati szintú versenyképességet a rendelkezésre álló fizikai eróforrások, a humán eróforrások, a hálózatosodás (networking), az innovációs képességek és az adminisztratív rutinok kompetenciáiként határozom meg. Ezek teszik lehetôvé a cég számára, hogy a fogyasztókat magas szinten szolgálják ki és hatékonyan versenyezzenek más cégekkel. A belsố erớforrások, képességek és készségek összessége teszi ki azokat a kompetenciákat, amelyeket egyrészt a fogyasztók igényeihez (kereslet), másrészt pedig az iparágban levó versenytársakhoz és a helyettesín̋ termékek elóllít́ihoz (ḱ́ń́lti tén écók) kell igazítani. A versenyképesség hét pillérje magyarázza a vállalati teljesítményt, amely nyereségességi, hatékonysági és növekedési mutatókkal mérhetó.

Az 1. ábrán látható koncepcionális modell szerint a versenyképesség hét pillérje közül öt, a Fizikai erôforrások, a Humán erớforrások, az Innováció, a Networking és az Adminisztratív rutinok alkotják a vállalat alapvető kompetenciáit. Ezek az alapkompetenciák teszi lehetővé, hogy a cég versenyképes legyen, azonban 
ehhez a kompetenciákat illeszteni kell a fogyasztókhoz (keresleti tényezók) és a versenytársakhoz is (kínála tényezók). A versenyképességet alapvetóen a nyereségességgel és a hatékonysággal mérhetjük, ugyanakkor a növekedési rátát és az exportkapacitást is gyakran alkalmazzák a versenyképesség sikerkritériumakén Mivel nyereségességi és hatékonysági adatok nem állnak rendelkezésre, vagy megbízhatatlanok (nyereség), elemzésünkben a versenyképességet elsôsorban a növekedéssel (árbevétel, alkalmazottak száma), másrész pedig az exporttal összefïgrésben vizsgálom. A változók részletes leírása az 1. mellékletben található.
A kisvállalati versenyképesség koncepcionális modellje

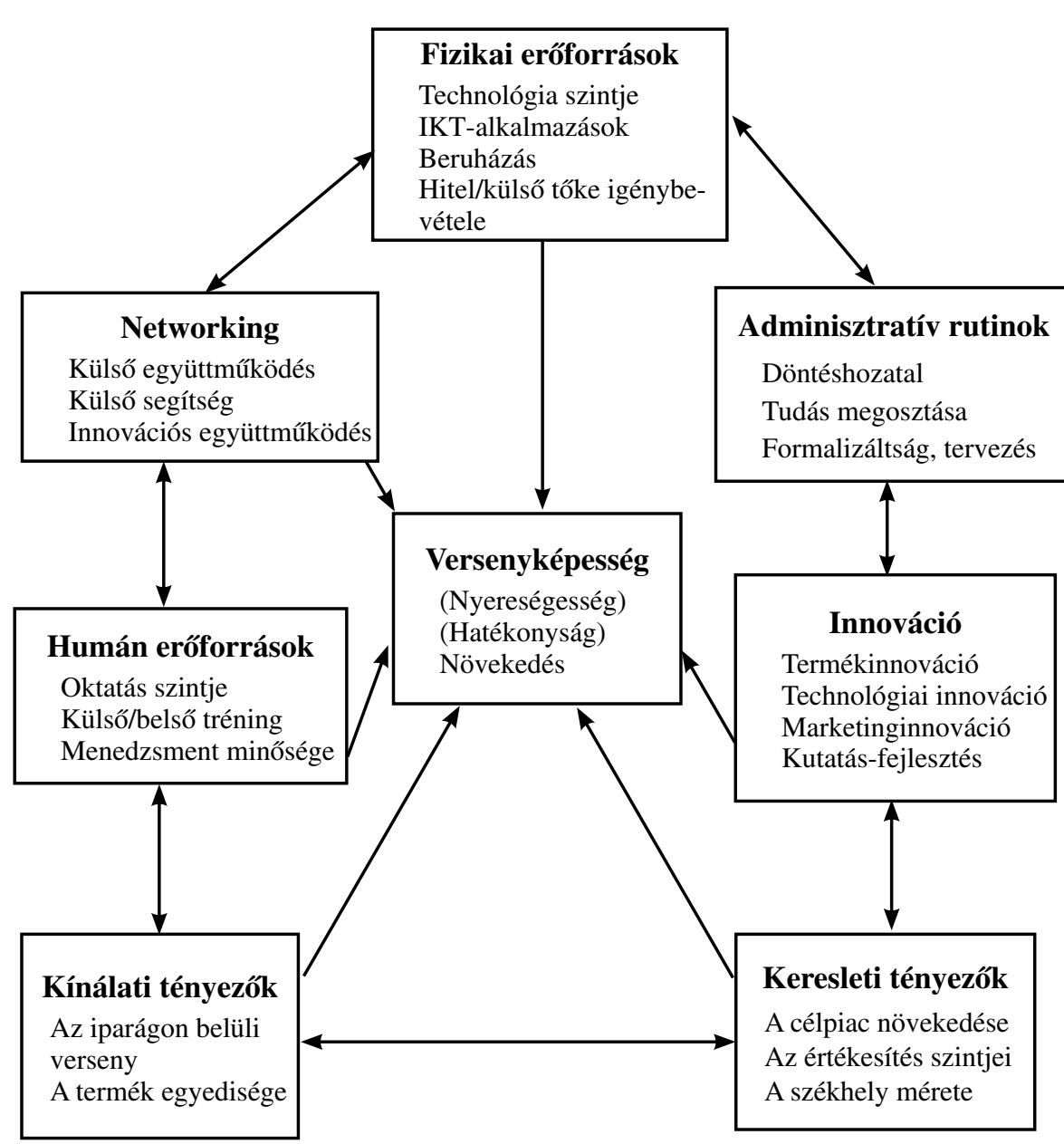

nek egymáshoz. A legtöbb versenyképességi indexet, y a Globális Versenyképességi Indexet vagy Chikán Atttila vállalati indexét a versenyképességi pillérek, tényezók súlyozott átlaga alapján számolják ki. Ez a fajta megoldás azonban eltekint attól, hogy az egyes tényezôk összefügghetnek, erôsíthetik, vagy éppen gyengíthetik egymás hatását. A vállalati stratégia kialakítása kapcsán azonban számos esetben kihangsúlyozzák az egyes elemek kiegyensúlyozását (pl. Kaplan - Norton, 1996; Miller and- Whitney, 1999; Porter, 1998). Ennél is tovab megy a Dennis Miller által alkotott konfiguamely azt álítja, hogy a rendszer ele1. ábra meit nem önmagukban, hanem a rendszer részeként kell tekintenünk (Dess et al., 1993, Miller, 1986). Ameddig az egyes elemek relatíve könnyen másolhatók, a kompetitív előny attól is függ, hogy milyen mértékben sikerül az elemeket összehangolni (Miller-Whitney, 1999,; Miller, 1996).

További kérdés, hogy az öszszehangolásnál mi legyen a viszonyitási alap. Az eddigi indexszámítások szerint ez az átlag. A Globális Versenyképessétag. dex esetében a versenyképesin dex esetében a versenyképességi rengor alati tenyezoket versenyhátánykênt, az állag felettieket versenyelônyként tărgyalják (Schwab, 2009). Az alapkompetencia elmélete szerint a vállalatnak arra kell fókuszálnia, miben a legnagyobb a versenyelőnye a többiekhez képest (Prahalad Hamel, 1990). Ez a fajta felfogás azonban a mi esetünkben csak korlátozottan érvényes, mivel az alapkompetenciák leginkább az egyes üzletágak közti válasz tás stratégiája vonatkoź́śn leginkább nagyvállalozásában, leginkább nagyvallalatoknál al-

A modell gyenge pontja, hogy a társadalmi hasznos- cepcionális modell pedig a versenyképesség általános ságot, az etikai normák elvárásainak történő megfelelést elemeit igyekszik megragadni, amelyeknek mindegyik nem tartalmazza. Hiányzik a külső környezeti tényezók cég esetében rendelkezésre kell állniuk.

egy jó része is, amelyek a vállalatok múködését alapvetôen befolyásolnák. Ugyanakkor az iparági hatások keresleti-kínálati viszonyokban jórészt tetten érhetố.

2) A versenyképesség tényezóinek azonosítása mellett fontos az is, hogy az egyes elemek hogyan illeszked-

Így marad a harmadik megoldás, ami szerint a versenyképességet a leggyengébb elem határozza meg, amely negatív hatást gyakorol a többi, relatíve jobb tényezőre is. A leggyengébb láncszem (Theory of Weakest Link) és a korlátok (Theory of Constraints)

VEZETÉSTUDOMÁNY

elméletei pontosan ezt állítják. A TOC szerint a rendszer teljesítménye a leggyengébb láncszem elmozdításźval vagy juvye a leggyenge bb láncszem elmozdít sával vagy javitasával éhetó el (Goldran, 1994). Ez a szenclet közzôn vissza a Hat Szlgma menedzsmentmódszernél is a termelés hatékonyságának növelése esetében (Stamatis, 2004).

A vállalati versenyképesség tényezói között megbúvó szúk keresztmetszetek fontosak lehetnek a cég stratégiájának alakítása során. A koncepcionális modell azt sugallja, hogy a fizikai eróforrások, a human erőforr sok, a networking, az adminisztratív rutinok, a keresleti és a kíńlati tényezók egyïttesen hatriozzak leti és a kínálati tényezôk együttesen határozzák meg a versenyképességet. Ha közöttük egyensúlytalansá van, akkor az negatív módon hat a teljes versenyképes-
ségre. Az egyik, vagy több tényezó magasabb értéke ségre. Az egyik, vagy tobb tényezó magasabb éréke csak részben javítja a versenyképességet, hiszen a szú keresztmetszet visszahúzó hatást gyakorol. Praktikus ez azt jelenti, hogy a hét pillér értékeit úgy módosítjuk, hogy az aktuális pillér értéket kapcsolatba hozzuk a leggyengébb pillér értékével, azaz csökkentjük, levonássa „,büntetünk” a szúk keresztmetszetért. A leggyengéb pillér így visszahúzó hatást gyakorol a többi pillérre. Javulás pedig úgy érhetô el, hogy a leggyengébb pillér javítjuk, hiszen így a többi pillér esetében is hatékon ságbeli javulást érhetünk el.

3) További problémát jelent, hogy a versenyképességi elméletek és az empirikus tanulmányok elsôsorban nagyvállalatokra készültek. A kkv-k elemzéséhez azonban figyelembe kell venni azt is, hogy a kisvállalatok nem kisméretú nagyvállalatok (Man et al., 2002). A kkv-k különböznek a nagyvállalatoktól többek között a menedzsmentben, a szervezeti rendszerben, stratégiában, az IKT-eszközök használatában vagy az innovációban is (Gray - Mabey, 2005; Tetteh - Burn, 2001; Malecki - Tootle, 1996; Verhees et al., 2004 Utterback - Suárez, 1993). A kisvállalatok fóleg helyi piacokon versenyeznek. A megfelelố erőforrások hiánya fóleg a humán területen, a finanszírozásba és az innováció eseteiben számottevő (Bridge et al., 2003; Storey 1994). Így a networking, a külsó kooperáció, a hatékony tudásmegosztási módszerek felérte-

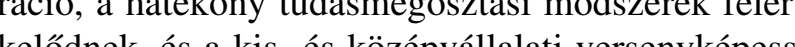
kelôdnek, és a is es kózépvallalati versenyképessé Dyer - Singh, 1998; Eisenhardt - Schoonhoven, 1996; Dyer - Singh, 1998; Eisenhardt - Schoon

A javasolt koncepcionális modell a kis- és középA javasolt koncepcionális modell a kis- és középvállalati specialitásokat két módon veszi figyelembe. sakor tekintettel voltam arra, hogy itt kisebb mére cégekról van szó: például a Kutatás-fejlesztés maximális szintjét már három év alatt egymillió Ft-ot meghaladó $\mathrm{K}+\mathrm{F}$ kiadással, vagy tartós $\mathrm{K}+\mathrm{F}$ együtt- múködéssel el lehetett érni. A másik kiemelt terület vállalatközi együttmúködés, amit nem csupán az állános együttmúködést és külsố segítségnyújtást kiejezó Networking változónál mértem, de figyelembe vettem más változóknál is. A Fizikai eróforrások esetében a hitel és a külsố tốkebevonás, az adminisztratív Rutinoknál a döntéshozatal külső támogatottsága, a Humán erốforrásoknál pedig a külsố tréning is szerepelt. Így azoknak a cégeknek is lehetôségük van magas versenyképességi pontok elérésére, amelyek nem aját eróforrásokra hanem együttmúḱöóśse, hálózati kapcsolatokra alapoznak.

\section{Adatleírás és módszertan}

Az adatgyújtés és az adatbázis jellemzói

A kutatást „A hazai vállalkozások alapítására, növekedésére, versenyképességére ható tényezók vizsgálata" címú NK 69283 számú OTKA pályázat finanszírozta. Az adatfelvétel során az alapadatok mellett a felmérés kilenc blokkot és 53 kérdéscsoportot foglalt magába, gyakorlatilag lefedve a vállalatok összes fố funkcionális területét a stratégiától, az innováción, a tudásmenedzsmenten, a humán erőforráson, a pénzügyeken, a kockázatkezelésen keresztül egészen a marketingig. A kérdések a 2004-2007-es idószzakra vonatkoztak. A jen cikk 2 a felóńs 24 kérzésra vonat-

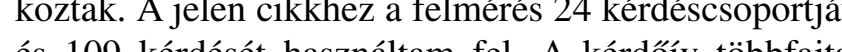

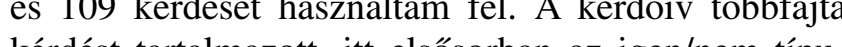
kérdést tartalnazott, itt elsősorban az igen/nem típusúlat alkalmaztam. A kodolás során a „nem tudom” válaszokat nemnek vettem. Az 1. ábra koncepcionális modelljének megfelelóen 22, 4-6 pontos Likert-skálás változó képezésére került sor (1. 1. melléklet).

A felmérés 2008. április-június időszakban történt, amelyet a Szociográf Piac- és Közvélemény-kutató készített. A telefonos egyeztetés után a kérdốiv kitöltésére személyes interjú keretében került sor a cég egyik olyan tulajdonosával, aki egyben a felsố vezetésben is részt vett (20 fó foglalkoztatott alatt), vagy az egyik felsô vezetôvel, aki nem volt feltétlenül tulajdonos (20 foglalkoztatott felett) A cégek kiválaszt́́x́choz az

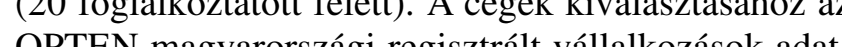
bázisa szolǵlt ${ }^{2}$ A ć́ bázisa szolgál.

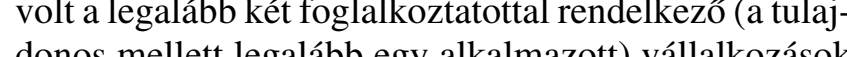
donos mellett legalâbb egy alkalmazott) vállalkozások körében. A vállalatokat véletlenszerúen választották ki, a Szociográf figyelembe vette a méretet, a régiót és az iparágat is (rétegzett reprezentatív). A minta méret szerinti megoszlása a Kozponti Statisztikai Hivatal (KSH) által jelentett múködô vállalkozások számával összehasonlítva az 1. táblázatban látható, a válaszadók arányával egyetemben.

\section{VEZETÉSTUDOMÁNY}



A minta vállalatainak megoszlása az alkalmazottak 2007-es száma alapján

\begin{tabular}{|c|c|c|c|c|c|c|c|}
\hline \multirow[t]{2}{*}{$\begin{array}{l}\text { Alkalmazottak } \\
\text { száma } 2007\end{array}$} & \multicolumn{2}{|c|}{$\begin{array}{l}\text { A vállalatok száma/százaléka } \\
2006^{*}\end{array}$} & \multicolumn{2}{|c|}{ Kezdeti minta } & \multicolumn{2}{|c|}{ Végsố minta } & \multirow[t]{2}{*}{$\begin{array}{c}\text { Válaszadás (\%) } \\
(\%)\end{array}$} \\
\hline & $\mathrm{db}$ & százalék & $\mathrm{db}$ & százalék & $\mathrm{db}$ & százalék & \\
\hline $2-9$ & 193,092 & 84,5 & 963 & 58,3 & 373 & 53,7 & 38,6 \\
\hline $10-49$ & 29,388 & 12,9 & 538 & 32,6 & 230 & 33,1 & 42,9 \\
\hline 50-249 & 5,010 & 2,2 & 127 & 7,7 & 75 & 10,8 & 59,1 \\
\hline 250 felett & 924 & 0,4 & 25 & 1,5 & 17 & 2,4 & 38 \\
\hline Összesen & 228,490 & 100,0 & 1628 & 100 & 695 & 100,0 & 41,4 \\
\hline
\end{tabular}

*Központi Statisztikai Hivatal (2008)

Mivel a kezdeti válaszarány $50 \%$ alatt volt, a várakozásokkal ellentétben, a kijelölt cégek számának nōkozéśre kerïlt sor, végül összesen 1628 céget kériïk velésére kén a felmérésben történô részvételre, amelybốl aértün

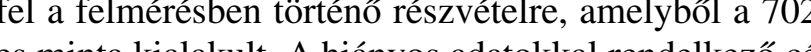
es minta kialakult. A hichyos adasokkal rendelkezố cégek tor 18 utan alakult ki a $695-0 \mathrm{~s}$ ininta, amely 678 kkv-t és 18 nagyvállalatot foglalt magába. A legkiseb méretû́ cégek feldúsulásának megakadályozása érdekében rétegzést alkalmaztunk.

\section{Az alkalmazott módszertan: A szúk keresztmet-} szetekért történó büntetés

A következó probléma, hogy a konfigurációs elméletnek megfelelóen milyen módon kombináljuk a változókat? A leggyengébb láncszem elméletnek megfelelő́n a pillérek korlátozott helyettesíthetőségét feltételezem, azaz az egyik pillér alacsonyabb szintjest feltételezen, azaz az egyik pillér alacsonyabb szintjé csak részben képes kompenzálni egy másik pillér enné magasabb êtcke. Ugyanakkor Miller (1986) szellemének megfelclôn (pillérek) együttes hatásmechanizmusa magyarázza versenyképességet. Az egyes tényezók kombinált hatásának számításához, a korlátozott helyettesíthetőség figyelembevétele mellett, új módszert alkalmaztam, amelyet eredetileg egy versenyképességi index számításához fejlesztett ki Ács és Szerb (2009) a szúk keresztmetszetekért történő büntetés (PFB) néven

A szúk keresztmetszetekért történő büntetés módszere igazodási pontként a vállalat versenyképességét képezó hét pillér közül a leggyengébbet tekinti igazodási pontnak. A leggyengébb pillérnél jobb teljesítményú pillérek értékeit egy logaritmikus függvény segítségével korrigálja, értelemszerúen csökkenti.

A versenyképességi pontok kalkulálásának lépéseit az alábbiakban mutatom be:

1. A pillérértékek kalkulálása. Az egyes pilléreket alkotó változókat átlagolással alakítottam ki. Ehhez azonban szükség volt a változók $0-1$ érték közöttire reket alkotó változók értékeit átlagolással számítottam ki, amely a cégek szintjén hét pillérértéket eredményezett.

. A szúk keresztmetszetekért történó büntetés (PFB) mértékének kiszámitása. Az egyes pillér szúk keresztmetszetért történő büntetés utáni értékét úgy kapjuk meg, hogy a legalacsonyabb pillérértékéhez hozzáadjuk a legalacsonyabb pillér érték és az aktúlis pillérérte

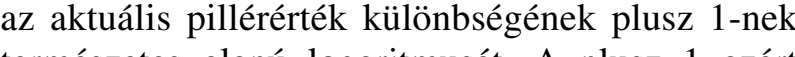
logaritmusát. A plusz 1 azért szerepel, hogy a logaritmikus számított értéke pozitív legyen $(\ln 1=0)$. Feltételezzük, hogy egy cég 7 pillérértéke közül a leggyengébb az innováció, 0,40-es normalizált értékkel. Ugyanakkor a humán erôforrás esetében a cég normalizált pillérértéke 0,60 , sokkal jobb. Azonban a gyenge innohuman erőforrás elő́nyei. A különbség az innovációs és a humánerőforrás-értékek között 0,20 , akkor $\ln (1+0,2)=0,18$. A szúk keresztmetszetért történô büntetés miatti igazított humánerooforrás-érték így 0,58 lesz a 0,60 helyett. A büntetés mértéke 0,60 büntetés mértéke is nagyobb lesz. Abban az extrém esetben, ha a különbség a maximális, 1 es éték, akkor az igazitúćck $0+102=0,699$ lesz, azaz a maxiḿlis bintetés $-, 0,699=0,301$. Ha az azaz a tényezố érték ugyanz, A PBF- éce ugyaz, akkor ninesen buntetes. figurációs elmélettel, hiszen a tényezók kombinált hatásmechanizmusa szerint számítja ki a versenyképességet.

3. Az egyes cégek versenyképességi pontjainak kalkulálása. Az adott vállalat versenyképességi pontjai egészen egyszerúen a PFB-módszerrel történó igazítás utáni pillérértékek összeadásával kaphatók meg. A maximálisan elérhetô pont így 7 lesz. konvertálására (normalizálás). Ezek után a pilléváció miatt nem teljes mértékben érvényesülnek a $0,58=0,02$. Ha a különbségek nagyobbak, akkor a

\section{Az eredmények vizsgálata}

A felmérésben szereplő 695 cég versenyképességi pontjainak a hisztogramja a 2. ábrán látható. Az eloszlás nagyjából normálisnak mondható, egy enyhe bal dőléssel. Az átlagos pontérték 1,96, az elérhetô max mális 7 pontnak mindössze a 28\%-a! A medián értéke 1,85, azaz nem különbözik lényegesen az átlagtó A legrosszabb cég 0,58 pontot, a legjobb cég pedig 4,8 pontot ért el, ez utóbbi a potenciálisan elérhetô po $68,7 \%$-a. A vállalatok csak mintegy $25 \%$-a ért el jobb eredményt, mint 2,28 (felső kvartilis), és mindössze 38 cég, a teljes minta 5,5\%-a ért el jobb eredményt, mi 3,5, az elérhetô pontok fele. Hanosúlyozni sziukséges, hogy a benchmarkok kijelölése, a maximális éték hogy a bench meghatározása a tónt. Feltételo törtent. Feltételezhế, hogy nenzetközi benchmarkok esetében ezek az ertékek még az eddigieknél is alacsonyabbak lennének. Összességében ezek az eredmenyek is azt az általános vélekedést látszanak igazoln hogy a versenyképesség a hazai kis- és középvállalatok körében általában alacsony, és még a legjobb cégeknek is van mit tenniük versenyképességük javítás érdekében.

A versenyképességi pontok hisztogramja a minta vállalatai esetében

\section{Hisztogram}

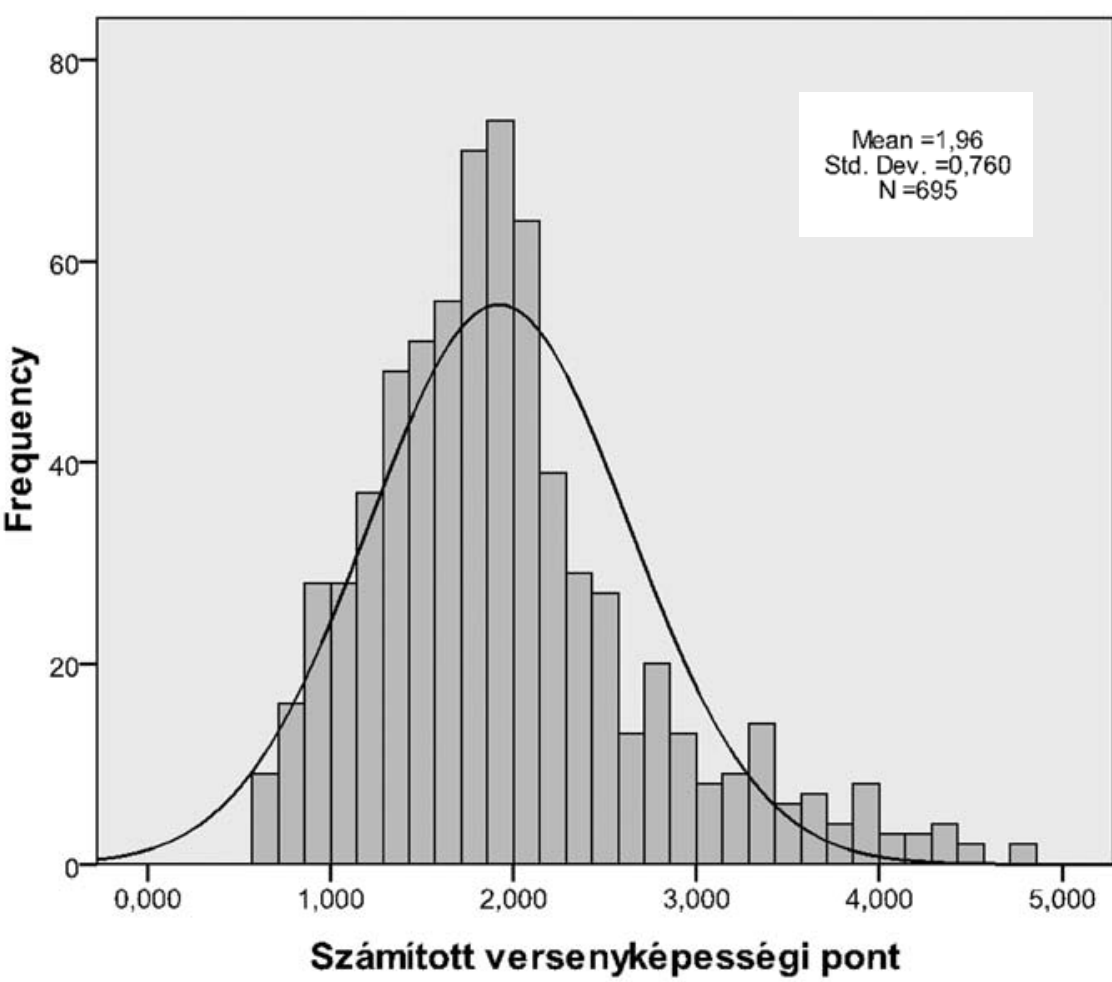

VEZETÉSTUDOMÁNY
A felmérés során megkérdeztük a vállalati vezetốet, mit gondolnak, van-e a cégnek olyan jellemzóje, mi egyedivé teszi, megkülönbözteti a többi hasonlô cégtőll, versenytárstól. Az értékelést egy 3-as fokozatú Likert- skála mentén kellett megadni, úgymint: nincsen ilyen elốny (1), részben versenyelóny (2) és versenyelôny (3). Az eredményeket a 2. táblázatban mutatom be.

Mint látható, a kkv-k általában legnagyobb versenyelőnyüknek a vevói igényekre történó gyors reagálást tartják, ahol mindössze a cégek negyede véli úgy, hogy ez náluk nem versenyelôny. Számos cégvezetố láthatón jó véleménnyel van saját vezetói, menedzse-

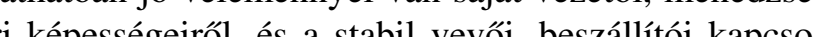

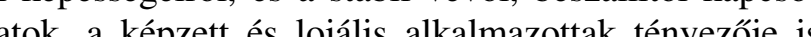

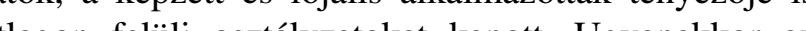
fokommunikációs eszközök alkalmaź́ ing

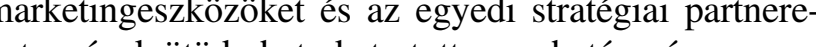
a cégek öode-hatoda tartotta meghatározó versenyeornynek. Hasonlóan kevesen szereznek jó pozíciót a

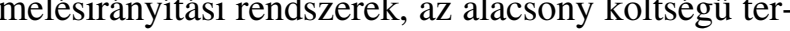
melés, vagy a kiváló elhelyezkedés révén. A véleméek, talân a cégvezetés túlértékelt képességeit kivéve, únnek. A kkv-k versenyelónyei általában véve 2ábra a kiadásokkal, költségekkel direkt módon nem, vagy nehezen mérhető, „puhább” tényezóknek köszönhetőek, amelyek ráadásul meglehetősen könnyen másolhatók, követhetók. A drágább, mások által nehezebben kơvethetó, tartósabb versenyelônyt biztosító tényezók esetében a kisvállalatok ritkábban jeleztek magas pontszámokat (2. táblázat).

A következókben azt vizsgálom, hogy mi a kapcsolat a vállalatvezetók szerinti versenyképességitényezókésaversenyképességi pillérek között (3. táblázat). A korrelációs koefficiensek szignifikáns, de csak közepesen erós vagy gyenge kapcsolatot A koreláció általábatot mutatnak. A korreláció áttalában a legmagasabb a szubjektív versenyképességi tényezôk és a versenyképességi pontok közôt. Bár az aktuális versenyképességi pillérek és a szubjektív vélemények nem ugyanazok, azt várnánk, hogy a hasonló kategóriák esetében magasabb a korreláció. Az egyedi termékek például a keresleti és a kínálati tényezókkel és az inno- 
A versenyképesség forrásai a minta vállalatai esetében

\begin{tabular}{|c|c|c|c|c|}
\hline \multirow[t]{2}{*}{ A versenyképesség forrása } & Átlag & Nem versenyelő́ny & $\begin{array}{l}\text { Részben verseny- } \\
\text { elóny }\end{array}$ & Versenyelő́ny \\
\hline & \multicolumn{4}{|c|}{ A válaszadók százalékában } \\
\hline Egyedi termékek & 1,86 & 41,58 & 31,08 & 27,34 \\
\hline Fejlett, haladó technológia & 1,80 & 46,33 & 26,91 & 26,76 \\
\hline IKT-eszközök alkalmazása & 1,58 & 61,15 & 19,86 & 18,99 \\
\hline Folyamatos innováció & 1,67 & 51,80 & 29,50 & 18,71 \\
\hline Alacsony költségú termelés & 1,65 & 53,53 & 27,48 & 18,99 \\
\hline Egyedi marketingmódszerek & 1,54 & 60,58 & 25,32 & 14,10 \\
\hline Gyors reagálás a vevối igényekre & 2,22 & 25,32 & 27,48 & 47,19 \\
\hline Termelésirányittási, minőségbiztositási rendszer & 1,60 & 59,28 & 21,87 & 18,85 \\
\hline Kiváló vezetés, menedzsment & 1,88 & 39,14 & 33,67 & 27,19 \\
\hline Magas képzettségú lojális alkalmazottak & 1,86 & 41,87 & 30,50 & 27,63 \\
\hline Kiváló elhelyezkedés & 1,67 & 52,95 & 27,19 & 19,86 \\
\hline Egyedi stratégiai partnerek & 1,56 & 60,00 & 23,88 & 16,12 \\
\hline Stabil beszállítói, vevối kapcsolatok & 1,89 & 41,73 & 27,05 & 31,22 \\
\hline
\end{tabular}

vációval hozhatók kapcsolatba, a kiváló HRM pedig a a kis- és középvállalatok versenyképességét. Érdemes humán erốforrásokkal. Ez az elvárás a 3. táblázat alap- azt is megjegyezni, hogy a korrelációs koefficiensek ján csak részben igazolódik. Ebból két következtetés relatíve magasak a networking és a versenyképesség vonható le, vagy a szubjektív vélemények nem kellóen szubjektív tényezói között, ami azt mutatja hogy a reálisak, vagy pedig a versenyképességbe bevont té- : kïlső erớforrások felhasználási ápesége nyezők nem minden tekintetben képesek megragadni versenyképesség fontos eleme.

Korrelációs koefficiensek a versenyképesség forrása

3. táblázat

\section{és a hét versenyképességi pillér között}

\begin{tabular}{|c|c|c|c|c|c|c|c|c|}
\hline A versenyképesség forrása & $\begin{array}{l}\text { Verseny- } \\
\text { képesség }\end{array}$ & Kínálat & Kereslet & $\begin{array}{c}\text { Fizikai } \\
\text { erófor- } \\
\text { rások }\end{array}$ & $\begin{array}{c}\text { Humán } \\
\text { erófor- } \\
\text { rások }\end{array}$ & $\begin{array}{c}\text { Innová- } \\
\text { ció }\end{array}$ & $\begin{array}{l}\text { Network- } \\
\text { ing }\end{array}$ & $\begin{array}{l}\text { Admin } \\
\text { rutinol }\end{array}$ \\
\hline Egyedi termékek & $0,43 * *$ & $0,40^{* *}$ & $0,29 * *$ & $0,22^{* *}$ & $0,13 * *$ & $0,26 * *$ & $0,27 * *$ & $0,22^{*}:$ \\
\hline Fejlett, haladó technológia & $0,42 * *$ & $0,28 * *$ & $0,30 * *$ & $0,21^{* *}$ & $0,21 * *$ & $0,23 * *$ & $0,34 * *$ & $0,22^{*}:$ \\
\hline IKT-eszközök alkalmazása & $0,32^{* * *}$ & $0,16 * *$ & $0,22^{* * *}$ & $0,13^{* *}$ & $0,21 * *$ & $0,14 * *$ & $0,35 * *$ & $0,16^{*}:$ \\
\hline Folyamatos innováció & $0,36^{* * *}$ & $0,18^{* *}$ & $0,28 * *$ & $0,19^{* *}$ & $0,17 * *$ & $0,18 * *$ & $0,35 * *$ & $0,23 *$ \\
\hline Alacsony költségú termelés & $0,13 * *$ & 0,06 & 0,06 & $0,08^{*}$ & 0,03 & $0,09 *$ & $0,16 * *$ & 0,05 \\
\hline Egyedi marketingmódszerek & $0,24 * *$ & $0,15 * *$ & $0,11^{* * *}$ & $0,13^{* *}$ & $0,18 * *$ & $0,09 *$ & $0,23 * *$ & $0,15^{*}:$ \\
\hline Gyors reagálás a vevối igényekre & $0,26 * *$ & $0,15^{* *}$ & 0,07 & $0,22^{* *}$ & $0,22 * *$ & $0,19^{* * *}$ & 0,07 & $0,18^{*}$ \\
\hline Termelésirányítási, minốségbiztositási rendsz. & $0,35 * *$ & $0,16^{* *}$ & $0,22 * *$ & $0,26^{* *}$ & $0,17^{* *}$ & $0,17^{* * *}$ & $0,30^{* *}$ & $0,25^{*}:$ \\
\hline Kiváló vezetés, menedzsment & $0,29 * *$ & $0,15^{* *}$ & $0,16^{* * *}$ & $0,21^{* *}$ & $0,21^{* *}$ & $0,10^{* * *}$ & $0,19 * *$ & $0,26^{* *}$ \\
\hline Magas képzettségú lojális alkalmazottak & $0,27 * *$ & $0,15 * *$ & $0,13^{* *}$ & $0,22^{* *}$ & $0,18 * *$ & $0,13^{* *}$ & $0,18^{* *}$ & $0,18^{*}$ \\
\hline Kiváló elhelyezkedés & $0,21 * *$ & $0,08 *$ & 0,05 & $0,16^{* *}$ & $0,11^{* *}$ & $0,11^{* * *}$ & $0,20 * *$ & $0,14 *$ \\
\hline Egyedi stratégiai partnerek & $0,29 * *$ & $0,09 *$ & $0,21^{* *}$ & $0,21^{* *}$ & $0,11^{* * *}$ & $0,17^{* * *}$ & $0,27 * *$ & $0,18^{*}$ \\
\hline Stabil beszállítói, vevói kapcsolatok & $0,32 * *$ & $0,13 * *$ & $0,15^{* * *}$ & $0,32 * *$ & $0,11^{* * *}$ & $0,22 * *$ & $0,16 * *$ & $0,24 *$ \\
\hline
\end{tabular}

\%-os szinten szignifikán

VEZETÉSTUDOMÁNY

\section{A vállalatok klaszter- és egyéni elemzése}

Ebben a fejezetrészben a versenyképességi modell és az eredmények további elemzését végzem el. A vállalatok egyéni versenyképességi pontjainak kalkulálása révén képesek vagyunk arra, hogy a vállalatokat rangsorba setében, azonban ezek a tényezók nem vettek részt a 隹

4. táblázat alapján a magyar kkv-között nagy küIonbségek vannak. Az egyes klaszterek versenyképességi pontjai 1,2-tốl 3,68-ig terjednek.

4. táblázat

\begin{tabular}{|l|c|c|c|c|c|c|c|c|c|}
\hline & 1 & 2 & 3 & 4 & 5 & 6 & 7 & 8 & Átlag \\
\hline Tervezett árbevétel-növekedés & 0,15 & 0,43 & 0,34 & 0,29 & 0,20 & 0,57 & 0,21 & 0,59 & 0,29 \\
\hline Tervezett alkalmazotti létszámnövekedés & 0,16 & 0,27 & 0,28 & 0,28 & 0,23 & 0,48 & 0,18 & 0,65 & 0,25 \\
\hline Az export árbevételbeli aránya & 0,04 & 0,16 & 0,79 & 0,08 & 0,93 & 0,06 & 0,07 & 0,86 & 0,18 \\
\hline Kínálati tényezók & 0,07 & 0,39 & 0,09 & 0,07 & 0,24 & 0,20 & 0,21 & 0,34 & 0,17 \\
\hline Keresleti tényezók & 0,51 & 0,73 & 0,73 & 0,68 & 0,61 & 0,76 & 0,55 & 0,82 & 0,62 \\
\hline Fizikai eróforrások & 0,25 & 0,51 & 0,43 & 0,29 & 0,37 & 0,42 & 0,38 & 0,59 & 0,35 \\
\hline Humán eróforrások & 0,21 & 0,41 & 0,30 & 0,29 & 0,26 & 0,29 & 0,45 & 0,42 & 0,32 \\
\hline Innovácí́ & 0,02 & 0,55 & 0,15 & 0,05 & 0,04 & 0,06 & 0,06 & 0,58 & 0,12 \\
\hline Networking & 0,10 & 0,52 & 0,25 & 0,52 & 0,36 & 0,27 & 0,24 & 0,71 & 0,30 \\
\hline Adminisztratív rutinok & 0,26 & 0,62 & 0,63 & 0,40 & 0,36 & 0,61 & 0,56 & 0,68 & 0,46 \\
\hline & 1 & 2 & 3 & 4 & 5 & 6 & 7 & 8 & \\
\hline Számított versenyképességi pont & 1,21 & 3,34 & 2,07 & 1,88 & 1,84 & 2,10 & 2,02 & 3,68 & 1,96 \\
\hline Vállalat mérete & 1,92 & 3,13 & 3,24 & 2,44 & 2,84 & 2,90 & 2,75 & 4,00 & 2,64 \\
\hline Cégek száma & 156 & 62 & 38 & 101 & 31 & 58 & 137 & 19 & 602 \\
\hline
\end{tabular}

állítsuk. Mivel azonban ezek a pontok mintegy sưritve tartalmazzák az információt, ezért nem teszik lehetôvé, hogy a vállalatok versenyképességét fokozó javaslatokat tehessünk. Ezért a további elemzést a hét pillér mentén érdemes folytatni. A valós különbségek elemzéséhez alkalmasabb a pillérek eredeti értékeit, és nem a PFB igazított értékeket felhasználni, hiszen a PFB-módszer csökkenti a tényezók közötti különbségeket. Két praktikus alkalmazást mutatok be az alábbiakban: egyrészt a cégek csoportosítását végzem el klaszzterelemzés segítségével, másrészt pedig néhány kiválasztott vállalat segítségével szemléltetem a versenyképességi modell és a PFB-módszer egyedi alkalmazhatóságát.

\section{A klaszterelemzés}

Ebben a fejezetrészben a vállalatok versenyképességi stratégiáit mutatom be a hét pillér mentén klaszterelemzés segítségével. A pillérek kombinációinak elemzése révén lehetôvé válik a magyar kkv-szektor cége domináns stratégiáinak elemzése is. A klaszterelemzés részét képezik a versenyképességi teljesítmény mérésének tényezőii, az értékesítés, az alkalmazottak számának tervezett nôvekedése és az export aránya az árbevételben. ${ }^{3}$ Ugyanakkor a versenyképességi pontok és a vállalat mérete is kalkulált minden egyes klaszter

A nyolc klaszterból a 8 számú klaszter 19 cége szeA nogioban, átlagos versenyképességi pontjuk 3,68. A versenyképességi eredményesség alapján is ók a legjobbak, az árbevétel, az alkalmazottak száma és az export területén a legmagasabb értékkel rendelkeznek. hét pillér közül ötben az elsốk, kettốben pedig a második helyen találhatók. Leggyengébb pontjuk a kínálatî tennyezôk. Ezek a cégek a kategoria legnagyobbjai, döntố mértékben közepes méretú cégek, amelyek láthatóan nem is a hazai, hanem a nemzetközi piacokon versenyeznek. A legnagyobb gond, hogy nagyon kevesen vannak.

Az átlagos versenyképességi pontok alapján a 2 . klaszter 62 cége a második, 3,34-es értékkel. A hét pillér mentén teljesítményük meglehetôsen kiegyensúlyozott. Itt is szillég lente azo

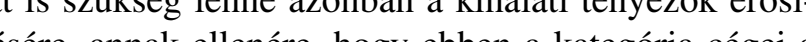
ére Jujobbak! Ez is azt támasztja alá, hogy a hazai cégek jo része már eleve erôteljes versennyel jellemezhetố erületen akar érvényesülni. A versenyképességi teljesitmények területén korántsem meggyőző̉ a cégek teljesitménye, az árbevétel növekedése még elfogadható, de az alkalmazotti létszám tervezett emelése éppen hogy atlag feletti. A cégek jelentôs része nem termel exportra, láthatóan a hazai piacot részesítik elónyben, itt viszont országos lefedettségre törekednek.

\section{VEZETÉSTUDOMÁNY}


A versenyképességi pontok tekintetében meglehetôsen nagy az ugrás a 6 . klaszter esetében, ahol a pontátla mindössze 2,10. A klaszter cégei átlagon felüli értékeket mutatnak a keresleti tényezók, az adminisztratív rutino és a fizikai erőforrások esetében. Elfogadható még a humán erơforrás és a networking is, az innováció viszont leggyengébb pont. Hasonlóan az elózố cégcsoporthoz, 6. klaszter vállalatai is hazai piacon versenyeznek, teljesítményük a tervezett árbevétel és alkalmazotti létszám növekedése tekintetben kifejezetten jó. Ennek némile ellentmond, hogy a versenyképességi pontok alig haladják meg az összes cég átlagát.

A 3. és a 7. klaszter cégei meglehetősen hasonló versenyképességgel rendelkeznek, azonban ezt a hé pillér más-más kombinációjával érik el. A 3. klaszter 38 cége igen jó a keresleti tényezók, a fizikai eróforrások és az adminisztratív rutinok területein, átlagos vagy némileg az alatti a networking és a humán eróforrás eseteiben. Az innováció ugyan átlag feletti, meglehetơsen alacsony, a kínálati tényezóknél viszont kritikus a helyzet. A 7. klaszter cégei ugyanakkor átlag feletti pillérértékekkel rendelkeznek a humán erőforrások, a kínálati tényezók és az adminisztratív rutino eseteiben. Mindehhez átlag körüli keresleti tényezók, fizikai erőforrások tartoznak. A kritikus pont az innováció. A két cégcsoport teljesítménye között azonb nagyobb a különbség, mint azt a versenyképességi pontok minimális eltéréséból gon a lń́nk: a 3. klaszter növekési teljestménye tlag fettiek, a 7. khstere azonban átag attiak. Elképzelhetó, hogy mindez az exporttelét 3. klasesitmény szerinti eltéréssel is magyarázható, zálják a hazai erốs verseny negatív hatásait.

Átlag alatti versenyképességi pontokkal rendelkeznek a 4. és az 5. klaszter cégei, amelyek meglehetôse hasonlítanak egymáshoz a keresleti tényező́k, a humán erôforrások és az adminisztratív rutinok eseteiben, 4. klaszter eredményei mindegyik esetben magasabbak viszont az 5. klaszterhez képest. Szignifikánsan jobb a 4. klaszter a networking területén. Mindegyikük gyenge pontja viszont az innováció (legalacsonyabb ték). A fizikai eróforrásoknál és a kínálati tényezókn-

zonban az 5. klaszter cégei a jobbak. Ráadásul az 5. laszter cégei erósek az exportban, ami nem mondható l a 4. klaszter cégeiról. A növekedés tekintetében az átlagosan jobb teljesítményt nyújtó 4 . klaszter átlag körüli, az 5. klaszter átlag alatti teljesítményt nyújt.

A legalacsonyabb versenyképessége a legnépesebb, 1. klaszter cégeinek van, amelyek minden egyes tényezô tekintetében az utolsó helyen szerepelnek. A legkritikusabb az innováció, de ennél alig jobb a kínálati tényezók szerint elért érték. A networking is azt mutatja, hogy ezek a cégek együttmúködést sem keresnek igaźn. A teljesítmények is ezt mutatják, a növekedési tervek

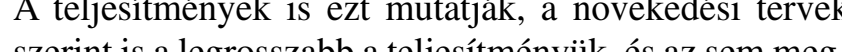
lepó, hogy exportálni sem igazán tudnak vagy akarnak.

\section{Egyéni elemzés}

Ameddig a klaszterelemzés elsősorban a gazdaságpolitikusoknak lehet hasznos, addig a vállalati szintú vizsgálat a cégek vezetóinek, menedzsereinek előnyös. Az elemzés a versenyképesség hét pillérje mentén történik, ahol az adott cég relatív teljesítményét veszszük górcső alá. Az 5. táblázat mutatja, hogy a vállalat hogyan helyezkedik el a cégek alsó, középső és felsố harmadához képest. A relatív pozíciót a színek szemléltetik, a világosszürke a kedvezố (felsố harmad), a középszïrke a középső (középső harmad), a sötétszïrke pedig a kedvezótlen (alsó harmad) helyzetre utsur. Vase tag betrel jelzet a (alón has-

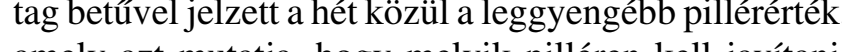
APFBAPFB-módszer alkalmazása miatt a leggyengébb pillér javítása pozitívan hat a tobbi pillerre is, igy a versenyképességi pont akár jelentós mértékben is növekedhet a szúk keresztmetszet csökkentése vagy felszámolása révén. Megjegyzésre érdemes az is, hogy esetleg nem a relatíve legkedvezótlenebb pozíciót jelentố színnel jelölt pillér esetében kell javítani, hanem másikon. Ennek oka az egyes pillérek eloszlásbeli különbsége: a Kínálat pillér normalizált átlagértéke pl. 0,17, a Keresletié pedig 0,62, tehát a Kínálat esetében lényegesen nagyobbak a relatív kïlönbségek, mint a Kereslet esetében. Az 5. táblázat négy kivélasztott cég esetében szectél. Az módszer használhatóságát.

5. táblázat

A választott cégek vizsgálata a hét pillér és a versenyképességi pontok alapján

\begin{tabular}{|c|c|c|c|c|c|c|c|c|}
\hline Cég száma & Kínálat & Kereslet & $\begin{array}{c}\text { Fizikai } \\
\text { eróforrások }\end{array}$ & $\begin{array}{c}\text { Humán } \\
\text { eróforrás }\end{array}$ & Innováció & Network & Rutinok & $\begin{array}{c}\text { Versenyké- } \\
\text { pességi pont }\end{array}$ \\
\hline 1 & 0,000 & 0,522 & 0,100 & $\mathbf{0 , 0 0 0}$ & 0,000 & 0,000 & 0,167 & 0,670 \\
\hline 81 & 0,250 & 0,667 & 0,546 & $\mathbf{0 , 6 3 5}$ & 0,000 & 0,333 & 0,917 & 2,600 \\
\hline 145 & 0,500 & 0,622 & 0,400 & $\mathbf{0 , 3 4 7}$ & 0,667 & 1,000 & 0,722 & 3,964 \\
\hline 154 & 0,750 & 1,000 & 0,525 & $\mathbf{0 , 3 8 2}$ & 0,667 & 0,917 & 0,556 & 4,441 \\
\hline
\end{tabular}

VEZETÉSTUDOMÁNY
Az 1. számú cég versenyképessége igen gyenge, mindössze 0,67 pontot ért el, és az összes pillér esetében a legalsó harmadhoz tartozik. Ráadásul háro esetben is 0 az elért pillérpontszám, így nem is egy, hanem mindjárt három szúk keresztmetszet alakult ki. Így ennél a cégnél olyan intézkedésre van szükség, amely egyszerre növeli a Humán eróforrás, az Innováció és Networking pilléreket.

A 81. cég versenyképessége némileg meghaladja az átlagot, viszont ezt az egyes területek igen egyenlótle teljesítményével éri el. Ameddig a Fizikai eróforrások, a Humán erón a Humán erónoúc rületen igen jok az êtekck A és a Networking pilléreknél gyengébb a teljesítmény. pont, aminek javulása révén a cég jelentősen tudná ver-

pont, aminek javulása ré

A 145-ös cég versenyképessége nemcsak meghaladja az átlagot, hanem lényegesen kiegyensúlyozottab mint az elóző cégeké. A leggyengébb pont a Humán erôforrás pillér, és ennél csak valamivel jobb a Fizik erőforrások szintje. A Networking-ben viszont kifejezetten jó a cég, azonban ehhez a többi tényezôt is hozzá kellene erôsíteni.

A 154-es cég a versenyképességi pontok alapján egyike a legjobbaknak, igen elókeló helyen szerepelve a rangsorban. Relatíve, a többi céghez képest minisztratí relo minisztrativ runinoke a pozíciója. Ugyanakkor a PFB-módszer a Humán erơororráso területén javasol intezkedést, amiben ugyan a legfelso harmadba tartozik a cég, mégis nagyobb a lemaradás a legjobb benchmarkhoz viszonyítva, mint az Admnisztratív rutinoknál.

Természetesen az adatbázis és módszer lehetôvé teszi, hogy hasonló elemzést bármelyik cégnél elvégezzünk. Ső́t, az elemzés mélysége is bővíthető a változôk bevonásával.

\section{Összefoglalás, értékelés és következtetések}

Ebben a cikkben a kisebb méretư vállalatok versenyképességének egy lehetséges kiszámítását és versenyképességi indexen alapuló vizsgálatát mutattam be. Tekintve, hogy a versenyképességi módszerek elsôsorban a nagyvállalatokra lettek kifejlesztve, egy új elemzés eszközt kellett kifejleszteni, amely figyelembe ves azt, hogy a kisebb méretú cégek nem kis nagyvállalatok. A javasolt koncepcionális modell 21 változ és hét pillért tartalmaz. Az erőforrás-alapú és Miller konfigurációs elmélete szolgált alapul ahhoz, hogy a változókból pillérek és a pillérekbő́l egy versenyképességi index alakuljon ki. Annak ellenére, hogy változók benchmark-értékeinek kialakítása során figyelemmel voltam a méretre és az együttmúködésben jio lehetóségekre, a modell még igy is a nagyobb cégeket preferálja. Mivel a kisebb mikrovállalatok jelentôs része helyi piacokon tevékenykedik, innovációja zéró, adminisztratív rutinjai pedig nincsenek, ezért az ilyen cégek versenyképességi pontjai igen alacsonyak. Ugyanakkor ez csak részben okoz gondot, hiszen a termelékenységi különbségek is magyarázhatók a mérettel. A hazai kkv-szektor nemzetközi szintú alacsony versenyképessége, legab́bbis részben, s. nagysz

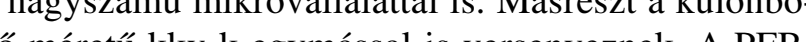
zón néretu kkv-k egynással is versenyeznek. A PFBmódszer megmutaja, hogy milyen módon nơvelhetố akár a legkisebb cégek versenyképessége is.

A rétegzetten reprezentatív, 695 céget tartalmazó minta képezte az empirikus vizsgálat alapját. A versenyképességi pontok számolása egy olyan új módszer segítségével történt, amely figyelembe veszi a szúk keresztmetszeteket is a versenyképességet alkotó hét pillér között. A versenyképességi pontok 0,58 és 4,81 között szóródtak, átlagosan 1,96 értékkel, nagyjából normál eloszlást mutatva. A hét pillér közül az Innováció volt a legalacsonyabb, megerősítve azt az általánosak mondható szakmai véleményt, hogy az innováció hazai vállalkozások egyik leggyengébb pontja. A Kínálat alig jobb, mint az Innováció, ami azt jelenti, hogy hazai kkv-k többsége igen intenzív versentö̈liby nyek között próbál meg érvényesülni. Problematikus Networking is, azaz cégeink kevéssé hajlamosak az együttmúködésre. A versenyképességi pontok, illetve az azt alkotó hét pillér szignifikáns, bár csak közepesen erős kapcsolatot mutatnak a vállalkozók szubjektív értékelésén alapuló versenyképességi tényezőkkel.

A klaszterelemzés a cégek nyolc csoportja között markáns különbségeket mutatott. Ugyanakkor a klasztereken belül népes számú, meglehetốsen homogén csoportok találhatók. A legalacsonyabb versenyképességú csoport a minta cégeinek $26 \%$-át tette ki, az thlagot lényesen meghaladó versenyképessé 81 cég azo lén cégen ér kiegyensúlyozatlan, még a legjobb csoport is gyenge Kinálat és a Humán erốforrások területén. Ugyanennek a két csoportnak a teljesitményét befolyásolja pozitívan az innováció, a többi cégnél, a minta 86\%anál alig van megújulás. Ez egyben azt is jelenti, hogy legversenyképesebb kkv-k a magyar gazdaságban szigetszerúen találhatók. Ráadásul a 15 legversenyképesebb cég közül 5 külföldi multinacionális vállalat hazai leányvállalat

\section{VEZETÉSTUDOMÁNY}


A kidolgozott módszertan alkalmas arra, hogy négy különböző versenyképességú vállalat esetébe prezentáltam a módszer használhatóságát és a stratégiai-fejlesztési javaslatok irányát. Némi zavart okozh ugyanakkor az, hogy az egyes pillérek szintjén a cégek területein. Több esetben meglehetősen gyenge relatîv teljesítménnyel is a legjobb 33\% közé lehetett kerüln ugyanakkor magasabb pontszámok sem mindig garanuálták, hogy a felső harmadba tartozik a cég.

Az eddigiek is azt mutaták, hogy a PFB-módsze lesztés, esetleg a skála finomítása szükséges. Ezen egy célzott adatfelmérés segíthet, amely már eleve az elméretból származó torzulásokat is csökkenteni lehene, még az eddigieknél is jobban figyelembe véve az együttmúködésben rejlő lehetôségeket. A benchmark megválasztásán is kell gondolkodni, és esetleg iparhogy a versenyképesség különbözik a kereskedelem, az ipar vagy a szolgáltatás területein, nem beszélve a csúcstechnológiás, biotechnológiai vagy szoftveres szörösére lenne szükség.

\section{Lábjegyzet}

Köszönetnyilvánitás: A tanulmány megírását az OTKA támo-

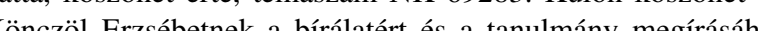
nyújtott javasalataiért.
További információrt 1. az OPTEN website-ját: http·///www. esetében jobbak voltak, mint az aktuális növekedés esetében.

\section{Felhasznált irodalom}

Acs, Z.J. (2006): The Growth of Cities., Edward Elgar, Cheltenham. Ács, Z.J. - L. Szerb (2009): The global entrepreneurship Index (GEINDEX), Foundations and

Ambastha, A. - Momaya, K. (2004): Competitivenes of frims: Review of theory, frameworks and models. Singapo Management Review, vol. 26, no. 1; First half 2004, $45-61$.

Barney, J. (1991): Firm resources and sustained competitive advantage. Journal of Management vol 17., no. 1. p. 99-120. vállalati szintú javaslatokat tehessünk. A kiválaszto eloszlása különbözik. Magas a szórás és nagyok a relatív különbségek az Innováció, a Kínálat, és a Networking alapvetően jól használható, ugyanakkor további fejméleti, koncepcionális modell szerint történhet. A cégági szintú standardokra kellene áttérni, hiszen biztos, iparágakról. Ehhez azonban az eddigi mintaszám töb-

opten.hu/ix2.php Felmerül a kérdés, hogy miért a tervezett és miért nem az aktuac-
lis növekedési értékek szerepelnek. A versenyképességi tényezót lis növekedési értékek szerepa a korrelációk a tervezett növekeded

Borsi B. (2005): Tudás, technológia és a magyar versenyépesség. PhD-értekezés. Budapesti Múszaki és Gazdaságtudományi Egyetem, Gazdaság- és Társadalom

Borsi B. - Papanek G. - Tompa T. (2007): A magyar gazdaság versenyképességét magyarázó tényezókról. Külgazdaság, 2007. 3-4. szám.

Bridge, S. - O'Neill, K. - Cromie, S. (2003): Understanding enterprise, entrepreneurship, and small business. 2nd Edition Palgrave Macmillan, London

Chikán A. (2006): A vállalati versenyképesség mérése. Pénzügyi Szemle, 51(1). p. 42-56.

Chikán A. (1997): Jelentés a magyar vállalati szféra nemzetközi versenyképességéról (a „Versenyben a világgal” kutatási program zárótanulmánya). BKE, Budapest

Chikán, A. - Czakó Á. (2009): Versenyben a világgal., Akadémiai Kiadó, Budapest

Chikán A.-Czakó E. (2006): A versenyképesség szintjei: fogalmak és értelmezések. Versenyképességi Kutatások múhelytanumány-sorezat, Versenyképessé Kutások Központ, Budapest ti versenyképesség a globalizálódó magyar gazdaságban. Akadémiai Kiadó, Budapest

globalizációnt: Verkrébenyképesséég iparágak szintién - - a globalizáció tükrében. PhD-disszertáció, BKAE, Budapest in Large and Small Firm Responses to Environmental in Large and Small Firm Responses to Environmental Analysis of Business Formations. Strategic Management Journal, vol. 19, no. 8. p. 709-728.

Dess, G.G. - Newport, S. - Rasheed, A.A. (1993): Configuration Research in Strategic Management: Key Issues and Suggestions, Journal of Management, vol. 19. issue 4, p. 775-796

Dyer, J.H. - Singh, H. (1998): The Relational View: Cooperative Strategy and Sources of Interorganizational Competitive Advantage. The Academy of Management Review, vol. 23, no. 4. p. 660-679.

Enyedi Gy. (2004): Regionális folyamatok a posztszocialista Magyarországon. Magyar Tudomány, 9. szám

Eisenhardt, K.M. - Schoonhoven, C.B. (1996): ResourceBased View of Strategic Alliance Formation: Strategic and Social Effects in Entrepreneurial Firms. Organization Science, vol. 7, no. 2, p. 136-150.

Foss, N.J. - Knudsen, C. (1996): Towards a competence theory of the firm. Routledge, London

Fujita, M. - Krugman, P. - Venables, A. (1999): The Spatial Economy, MIT Press, Cambridge MA.

Goldratt, E.M. (1994): The Goal: A Process of Ongoing Improvement. North River Press, Great Barrington,

Grant, R.M (1991): Toward the resource-based theory of competitive advantage: Implications for strategy formulation. California Management Review, Spring, 33, 3. p. 114-135.

VEZETÉSTUDOMÁNY
Grant, R.M. (1996): Toward a Knowledge-Based Theory of the Firm. Strategic Management Journal, vol. 17, Winter Special Issue, p. 109-122.

Gray C. Mabey $C$. (2005): Management Development Key Differences between Small and Large Businesses in Europe. International Small Business Journal, vol. 23 , no. 5, p. $467-485$

Hakansson, H. - Snehota I. (1989): No business is an island The network concept of business strategy. Scandinavian Journal of Management, vol. 5, p. 187-200.

Horváth Gy. (szerk.) (2006): Régiók és települések versenyképesssége. MTA Regionális Kutatások Központja, Pécs

Hoványi G. (1999): A vállalati versenyképesség makrogazdasági és globális háttere. Michael Porter két modelljének továbbfejlesztése. Közgazdasági Szemle, 46(11), p. 1013-1029.

Jovanovich, B. - McDonald, J. (1984): The life cycle of competitive industry. Journal of Political Economy, 04(2). p. 322-347.

IMD yearbook (2010): IMD World Competitiveness Yearbook. IMD, Lausanne

Kadocsa, Cy. (2006): Resesch of Conptitivess Fonter of SME. Acta Polytechnica Hungarica, vol. 3, no. 4, p. 71-84.

Kaplan, R.S. - Norton, D.P. (1996): Linking the Balance Scorecard to strategy. California Management Review, Fall, p. 53-79.

Kkv-k helyzete (2009): A kis- és középvállalkozások helyzete. Éves jelentés 2008. Nemzeti Fejlesztési és Gazdasági Minisztérium, Budapest

Nelson, R. (1992): Recent Writing on competitivenes: Boxing the compass., California Management Review, 34(2). p. 127-137.

Krugman, P. (1994): Competitiveness: A Dangerous Obsession.; Foreign Affairs; vol. 73, issue 2, p.

Lengnick-Hall, CA. (1992): Innovation and competitive advantage: What we know and what we need to learn., Journal of Management, 18(2). p. 399-429.

Lengyel I. (2000): A regionális versenyképességról., Közgazdasági Szemle, vol XLVII. December. p. 962-987.

Lengyel I. (2006): A regionális versenyképesség értelmezés es piramismodellje. Területi Statisztika, 2. p. 148-166.

Lengyel I. (2001): Iparági és regionális klaszterek. Tipizálátudomány, vol. 32 no. 10. p. 19-43.

Lengyel I. (2003): Verseny és területi fejlódés: térségek versenyképessége Magyarországon. JATE Press, Szeged.

Malecki, E.J - Tootle, D.M. (1996): The role of network in small firm competitiveness. International Journal of Technology Management. Vol. 11, no. 1/2. p. 43-57.

Man, T.W.Y-Lau, T. -Chan, K.F. (2002): The competitiveness of small and medium enterprises. A conceptualization with focus on entrepreneurial competencies. Journal of Business Venturing, Vol 17, pp. 123-142.

Malerba, F. (2002): Sectoral systems of innovation and production. Research Policy, 31, p. 247-264.
Márkus G. - Potó Zs. - Zsibó Zs. - Soó J. - Schmuck R. Duczon A. (2008): A mikroszintü regionaális versenyképesség mérése.; Vállalkozás és Innováció, vol. 2, s. 1. p. 30-53.

cGahan, A.M. (1999): Competition, Strategy and Business Performance., California Management Review, 41(3), p. 74-101.

er, D. (1986): Configurations of Strategy and Structure Towards a Synthesis. Strategic Management Journal. 7, p. $233-249$

per, D. - Whitney, J.O: (1999): Beyond Strategy: Configuration as a Pillar of Competitive Advantage. Business Horizons. May-June, p. 5-17.

Némethné G. A. (2009): A kis- és középvállalatok versenyképessége,. PhD-disszertáció, Széchenyi István Egyetem Regionális- és Gazdaságtudományi Doktori Iskola, Győrr Perry, M. (1999): Small firms and network economies. Routledge Studies in Small Businesses, London

Peteraf, M.A. (1993): The cornerstones of competitive advantage: A resource-based view. Strategic Management Journal, Mar 1993; 14, 3; p. 173-191.

Porter, M.E. (1998): On competition. Harvard Business School Press, Boston MA

Porter, M.E. (1990): The Competitive Advantage of Nations. The Free Press, New York 1990

Porter, M.E. (1996): Competitive Advantage, Agglomeration Economies, and Regional Policy. International Regional Science Review, April 19, p.: 85-90.

Prahalad, C.K. - Hamel, G. (1990): „The Core Competence of the Corporation.", Harvard Business Review, 68 (May-June), p.: 79-91.

Ray, G. - Barney, J.B. - Muhanna, W. (2004): Capabilities, business processes, and competitive advantage: choosing the dependent variable in empirical studies., Strategic Management Journal, 25, p. 23-37.

Rugman, A.M. - Verbeke, A. (2001): Location, Competitiveness, and the Multinational Enterprise. In: Rugman, A.M. - Brewer, T.L. (eds): The Oxford Handbook of International Business, Oxford University Press, Oxford, p.146-180.

Schwab, K. (ed.) (2009): The global competitiveness report 2009-2010. World Economic Forum, Geneva

Scott, A.J. - Storper, M. (2003): Regions, globalization, development. Regional Studies, 37, p. 579-593

matis, D.H. (2004): Six Sigma Fundamentals: A Complete Guide to the System, Methods, and Tools. Productivity Press, New York

Storey, D. (1994): Understanding the small business sector, Routledge, London

Szavetz A. (2004): Gazdasági szerkezet és versenyképesség. Világgazdasági Kutatóintézet Múhelytanulmányok 59. szám

Szerb L. (2000): Kisvállalati gazdaságtan és vállalkozástan, Pécsi Tudományegyetem Kiadó, Pécs 
Tetteh, E. - J. Burn, J. (2001): Global strategies for SMebusiness: applying the SMALL framework. Logistic Information Management, vol. 14, issue: 1/2, p. 171-180. Torok A. (2007). A vensenykepesseg egyes jogi es szabályoási feltételei Magyarországon. Közgazdasági Szemle 54(12), p.1066-1084.

Torok A. (1989). Komparativ elónyök, versenyképesség, pacmúkodes. Ipargazdasagi Szemle, 1989/3. p. 23-34.

kez (19) . Verseny a versenyképessegerr? Mikroszferakezelési politikák az Európai Unióban és Magyarorsz gon. Miniszterelnoki Hivatal, Budapest

Cok, J.M. - Sumez, F.F. (1993): Innovatio Competition, and Industry Structure, Research Policy, vol. 23, no. 1. p. 1-2 Orientation, Innovativeness, Product Innovation, an
Performance in Small Firms", Journal of Small Business Management 42, no. 2, p. 134-154.

Veress J. (szerk.) (2009): A magyar gazdaság versenyképessége 2007-2009, Szemelvények a Gazdasági Versenyképesség Kerekasztal tanulmányaiból és javaslati anyagaiból. Miniszterelnöki Hivatal, Budapest

Viszz E. (szerk.) (2006): Versenyképességi évkönyv. GKI Rt. - Miscrosoft, Budapest

Viszt E. (szerk.) (2009): Versenyképességi évkönyv. GKI Gazdaságkutató Zrt., Budapest

-Jonas, A.E.G. (2004): Competitive city-regionalism as a politics of space: a critical reinterpretation of the new regionalism. Environment and Planning A 36, p

B. (1984): A Resource-Based View of the Firm. Strategic Management Journal, 5(2). p.171-180.

\section{MELLÉKLET}

Az elemzéshez felhasznált változók és pillérek leírás

\begin{tabular}{|c|c|}
\hline Pillér/változók & Leírás \\
\hline \multicolumn{2}{|r|}{ Kínálati tényezók } \\
\hline Verseny az iparágon belül & $\begin{array}{l}\text { A verseny intenzitása az iparágon belïl, } 3 \text { fokozatú Likert-skálán mérve: 1: sok versenytárs, } \\
\text { 2: néhány versenytárs, 3: nincsen versenytárs }\end{array}$ \\
\hline A kínált termék egyedisége & $\begin{array}{l}\text { A fogyasztók száma, akik a vállalat jellemző termékét újnak találják } 3 \text { fokozatú Likert-skálán } \\
\text { mérve: 1: senki, 2: többen, 3: mindenki }\end{array}$ \\
\hline \multicolumn{2}{|r|}{ Keresleti tényezók } \\
\hline A célpiac növekedése & $\begin{array}{l}\text { A piac jövóbeli növekedési üteme } 4 \text { fokozatú Likert-skálán mérve: } 1 \text { : jelentósen csökken } \\
\text {...4: jelentősen nó }\end{array}$ \\
\hline A célpiac mérete & $\begin{array}{l}\text { Az értékesítés területének földrajzi kiterjedtsége } 6 \text { fokozatú Likert-skálán mérve: 1: egy hely egy } \\
\text { értékesitési pont ...6: országos szintú }\end{array}$ \\
\hline A célpiac terjedelme & $\begin{array}{l}\text { Az értékesítési hely nagysága } 5 \text { fokozatú Likert-skálán mérve: 1: } 2000 \text { fó lakos alatt } \\
\text {...6: Budapest }\end{array}$ \\
\hline \multicolumn{2}{|r|}{ Fizikai eróforrások } \\
\hline $\begin{array}{l}\text { Az alkalmazott technológia } \\
\text { szintje }\end{array}$ & $\begin{array}{l}\text { Az alkalmazott technológia szintje } 6 \text { fokozatú Likert-skálán mérve 1: jelentősen az iparági átlag } \\
\text { alatt ...6: világszintú új technológia }\end{array}$ \\
\hline IKT-eszközök alkalmazása & $\begin{array}{l}\text { Az info-kommunikációs eszközök alkalmazási intenzitása } 5 \text { fokozatú Likert-skálán mérve 1: 1-2 } \\
\text { IKT-eszközt alkalmaz ...5: 9-10 IKT-eszközt alkalmaz } \\
\end{array}$ \\
\hline Beruházás & A beruházás nagysága a 2004-2007 idốszakban 5 kategóriában 1: $0 \mathrm{Ft}$...5: 100 millió Ft felett \\
\hline Külső pénzügyi források & $\begin{array}{l}\text { A vállalat külső́ pénzügyi erớforrások használata iránti hajlandósága } 4 \text { fokozatú Likert-skálán } \\
\text { mérve: 1: nincsen külsớ forrás, 2: rövid távú hitel, 3: hosszú távú hitel, 4: hosszú távú hitel + küló } \\
\text { tókebevonás }\end{array}$ \\
\hline \multicolumn{2}{|r|}{ Humán erốforrások } \\
\hline $\begin{array}{l}\text { A humán eróforrás képzettségi } \\
\text { szintje }\end{array}$ & $\begin{array}{l}\text { A humán eróforrás jelentősége, ami a felső́fokú végzettséggel rendelkezó alkalmazottak számának } \\
\text { és arányának kombinációja }\end{array}$ \\
\hline Belső és külső tréning & $\begin{array}{l}\text { Az alkalmazottak aránya akik külső́ vagy belsố tréningen vettek részt a 2004-2007-es időszakban } \\
5 \text { fokozatú Likert-skálán mérve: 1: senki sem ...5: az alkalmazottak több mint 75\%-a }\end{array}$ \\
\hline A menedzsment minősége & A fő̉ döntéshozó menedzsment képességeinek kombinált változója 5 fokozatú Likert-skálán mérve \\
\hline
\end{tabular}

VEZETÉSTUDOMÁNY

\section{Innováció}

\begin{tabular}{|c|c|}
\hline \multicolumn{2}{|r|}{ Innováció } \\
\hline Termékinnováció & $\begin{array}{l}\text { Termékinnováció 2004-2007-ben, } 4 \text { kategóriában 1: nincsen innováció 2: megújitott termék, 3: új } \\
\text { termék a cég szintjén, 4: országosan új termék }\end{array}$ \\
\hline Technológiai innováció & $\begin{array}{l}\text { Technológiai innováció 2004-2007-ben, } 4 \text { kategóriában: 1: nincsen innováció 2: megújított tech- } \\
\text { nológia, 3: új technológia a cég szintjén, 4: országosan új technológia }\end{array}$ \\
\hline Marketinginnováció & $\begin{array}{l}\text { A marketinginnováció intenzitása a 2004-2007-es idószakban, } 5 \text { kategóriában: 1: nincsen innová- } \\
\text { ció ...5. } 6 \text { db. feletti marketinginnováció }\end{array}$ \\
\hline Kutatás és fejlesztés $(\mathrm{K}+\mathrm{F})$ & $\begin{array}{l}\text { A K+F kiadás és kooperáció intenzitása } 5 \text { fokozatú Likert-skálán mérve, 2004-2007: 1: nincsen } \\
\mathrm{K}+\mathrm{F} \text {...5: } \mathrm{K}+\mathrm{F} 1 \text { millió Ft felett vagy } \mathrm{K}+\mathrm{F} \text { együttmúködés másokkal }\end{array}$ \\
\hline \multicolumn{2}{|r|}{ Networking } \\
\hline Külsố együttmúköódés & $\begin{array}{l}\text { A külső együttmúḱödés intenzitááa } 4 \text { fokozatú Likert-skálán mérve 2004-2007: 1: nincsen együ̈t- } \\
\text { múködés ...4: több mint négyféle együttmúködés }\end{array}$ \\
\hline Külső segítség igénybevétele & $\begin{array}{l}\text { A külső segítségnyúttás } 10 \text { kategóríajának az átlagából képzett intenzitási mutató, } 5 \text { fokozatú } \\
\text { Likert-skálán mérve: 1: nincsen segítség, 2: 1-1,5 átlag, 3: 1,51-2,0 átlag, 4: 2,01-3,0 átlag, 5: 3,01 } \\
\text { feletti átlag }\end{array}$ \\
\hline Innovációs együttmúködés & $\begin{array}{l}\text { Az innovációs együttmúḱödé́s intenzitááa } 4 \text { fokozatú Likert-skálán mérve, 2004-2007: 1: nincsen } \\
\text { együttmúködés ...4: rendszeres együttmúködés }\end{array}$ \\
\hline \multicolumn{2}{|r|}{ Adminisztratív rutinok } \\
\hline Döntéshozatal & $\begin{array}{l}\text { A döntéshozatal módja, } 5 \text { fokozatú Likert-skálán mérve: 1: egyszemélyes döntéshozatal } \\
\text {...5: kollektív döntéshozatal külső segítséggel }\end{array}$ \\
\hline Tudás megosztása & $\begin{array}{l}\text { A tudásmegosztás intenzitása } 4 \text { fokozatú Likert-skálán mérve:1: nincsen tudásmegosztás } \\
\text {...4: rendszzeres találkozók/több mód }\end{array}$ \\
\hline Formalizáltság, tervezés & $\begin{array}{l}\text { Az adminiszztratív rutinok formalizáltsága } 4 \text { fokozatú Likert-skálán mérve, amely a munkaköri } \\
\text { leérásokat, szervezeti leírást, üzletie és stratégiai tervezést tartalmazza }\end{array}$ \\
\hline
\end{tabular}

Cikk beérkezett: 2010. 3. hó

Lektori vélemény alapján véglegesítve: 2010. 7. hó

\section{KEDVES OLVASÓ! \\ KÉRJÜK, NE FELEJTSE EL MEGÚJIITANI 2011-RE SZÓLÓ ELÓFIZETÉSÉT!}

\section{VEZETÉSTUDOMÁNY}

